\title{
TRANSITIONAL MECHANISMS TO FACILITATE TAX REFORM
}

\author{
RICHARD D. HOBbET*
}

The United States rediscovered in I969, if it had forgotten the lessons of the past, how difficult it is to make major changes in its income tax laws which can appropriately be labeled "reform." Specific improvements are of course made from time to time, and Ig69 certainly saw more than its share of these. Occasionally, something such as withholding is enacted which could be considered a major innovation as well as an improvement in the law. But "reform" of the tax laws implies something more. It at least raises the expectations of the public that, when the reform is completed, the tax law will provide for a distinctly fairer distribution of the burden of government expenditures.

Measured against these public expectations, not only the final enactment in 1969 but also both the I968 Treasury proposal, ${ }^{1}$ which was orphaned by President Johnson's refusal to submit it to Congress, and the later proposal by the Nixon Treasury ${ }^{2}$ fall short. This is not a criticism of the architects of those proposals or of the final result but a recognition that the political realities are such that genuine reform would create such havoc with existing economic relationships that any proponent of true reform will immediately be stamped as politically naive and perhaps as dangerously subversive.

The reasons for the political barriers to genuine tax reform have been explored in other places, ${ }^{3}$ and no attempt will be made here to repeat them. Instead, it is my purpose to explore several methods by which extensive reform could be achieved in gradual steps over a period of years in such a way as to eliminate most of the pain and the windfalls of the resulting economic adjustments. The development of such transitional mechanisms would clear away many of the obstacles that now impede substantial progress toward genuine tax reform.

The I969 Tax Reform Act ${ }^{4}$ and its legislative history provide an effective vehicle for consideration of transitional mechanisms. In its attempt to impose some minimum tax on all taxpayers having substantial amounts of real economic income, Congress considered and rejected two proposals that could be used to achieve a gradual transition to a radically different tax system. Instead, it adopted a type of minimum tax that not only does little to improve the equity of the law but has

- Professor of Law, Duke University.

1 U.S. Treasury Dep't, Tax Reform Studies and Proposals (Comm. Print 1969) [hercinafter cited as TAX Reforar Studies].

${ }^{2}$ Hearings on the Subject of Tax Reform Before the House Comm. on Ways and Means, 9rst Cong., Ist Sess., pt. 14 (1969) [hereinafter cited as 1969 House Hearings].

${ }^{3}$ Sec, e.g., L. Eisenstein, The Ideologies of Taxation (I96r).

'Pub. L. No. 9I-I72 (Dec. 3r, I969). 
little merit as a method for changing the tax law. This article will analyze these three approaches to a minimum tax, not in respect to their merits as minimum tax provisions but as potential transitional techniques in achieving meaningful tax reform.

Introductory to this, however, it will first be necessary to consider the nature of tax reform. If one wants to reform the law, he must begin with at least a general idea of the model tax system to be substituted for existing law. Next, to understand the need for finding a transitional mechanism, it will be necessary to examine briefly the political and economic barriers impeding tax reform. Finally, I will turn to the ways in which change in the tax law can be achieved without causing substantial dislocations in the economic relationships that have emerged under existing law. As indicated above, the hope is that discovery and utilization of an effective transitional mechanism will smooth the way for genuine tax reform.

\section{The Nature of Tax Reform}

\section{A. The Goals to be Accommodated}

The basic model against which tax reform should be tested recognizes the desirability of government spending to provide a variety of services and that the first and primary goal of the tax system should be to distribute the obligation of paying for these services as equitably as possible.

A model tax system should also be as nearly neutral as possible. Professor Surrey has defined neutrality as follows: "The tax system should to the maximum extent possible leave unchanged consumer and business choices between alternative activities." Neutrality, however, is the attribute that must give way whenever departures are made from the theoretical model in order to advance political, economic, or social goals.

Departures from the model to prevent undue complexity in administration of the law are also widely accepted as necessary under today's conditions of record keeping, methods of computation, and enforcement. For example, it is generally thought that the accretion principle must give way to taxing appreciation and recognizing declines in value at the time the gains or losses are realized. ${ }^{6}$ Likewise, although there is much pressure for adding imputed rent on owner-occupied houses to the income tax base, undue complexities would be added to the law were this to be carried to the extreme of trying to tax all items of imputed income arising from the consumption of one's own goods and services. ${ }^{7}$

\footnotetext{
"Surrey, Tax Policy and the Private Economy, 35 GEo. Wash. L. Rev. 389 (1966).

- See Musgrave, In Defense of an Income Concept, 8r Harv. L. REv. 44, 60 (r967). Galvin lists unrealized appreciation as one of the items omitted from the broadened tax bases described in the American Bar Foundation-funded project, and notes, "These factors would have to be considered in any major study, since they are an integral part of the Haig-Simmons definition." Galvin, History of the Substantive Tax Reform Project, in Studies in Substantrve Tax Reform 3, 9 (A. Willis ed. x969).

'See, e.g., Cohen, Administrative Aspects of a Negative Income Tax, II7 U. Pens. L. REv. 678, $684-85$ (1969).
} 
Departures from the model are also widely advocated as a means of selectively eliminating the neutrality of the law, thereby providing an incentive for some taxpayers either to engage in some type of desired activity or to avoid some activity. The investment credit was hailed by some economists and lawyers as a desirable form of encouraging investment in new plant and equipment, ${ }^{8}$ and today its removal has predictably been criticized. ${ }^{9}$ And of course the favored treatment of exempt organizations and charitable contributions has long been justified by the desirability of maintaining a strong private and pluralistic response to problems that would otherwise have to be met by governmental, and supposedly monolithic, action.

The major broad economic policy often espoused as a legitimate and important goal of tax policy, justifying a departure from neutrality, is the balancing of the incentives to consume or invest. To this could be added the encouragement of work because this incentive, too, is frequently espoused as an important goal of our tax system. ${ }^{10}$ Another goal often mentioned is the need for the tax law to encourage risk taking. This is really an aspect of the first policy above, the encouragement of investment. When it is used as a stated goal for tax policy it is used in the sense of asking the government to assume a portion of the risk and distribute this among the taxpaying public as a whole, in order to reduce the risk to the individual taxpayer benefited.

With respect to the balancing of incentives to consume and invest, most of the emphasis in this country has been on encouragement of investment, thrift, or savings as a necessary ingredient of a growing economy. This is said to be necessary not only to replace capital which is consumed but also to add to the resources available for growth in the economy. In the legislative process a variant of this argument is heard time and time again, not with respect to the broad economic goal but in the alleged imperative to provide necessary incentives for investment in specific industries or assets. In 1969 a great deal of testimony was heard about the need to encourage investment in housing, food production, exploration for oil and gas, railroad rolling stock, and state and local governmental facilities. Thus the argument becomes refined to the point not only of encouraging the direction of the total resources of the country towards savings and investment in general but also encouraging an allocation of resources to specific types of investment.

Although generally there has been primary emphasis on incentives to save and

\footnotetext{
${ }^{8}$ E.g., J. Pechman, Federal Tax Policy, 120-23 (1966); Surrey, Federal Tax Policy in the 1960's, I5 Buffalo L. Rev. 477,478 (I966).

${ }^{\circ}$ Saulnier, Tax Reform Bill: Exchanging Old Inequalities for New?, Wall Strect Journal, Oct. 13, I969, at 18 , col. 3 .

${ }^{10}$ In a 1963 resolution subsequently adopted by the American Bar Association, the Committec on Substantive Tax Reform of the ABA's Section of Taxation proposed "the continuance of inquiry and research by appropriate committees of the Section of Taxation leading to the objectives of establishing a fair and equitable tax system, broadening the tax base, and providing incentives for work and investment." Resolutions on Substantive Tax Reform, I6 ABA TAXation Section ANn. Rep. 4-5 (I963). See also Saulnier, stupra note 9.
} 
invest, President Kennedy in 1963 proposed a substantial revision of the tax system, parts of which proposal were enacted in the Revenue Act of $1964,{ }^{11}$ for the principal purpose of encouraging consumption. In the President's message to Congress of January 24, 1963 , he stated, "[T] he largest single barrier to full employment of our manpower and resources and to a higher rate of economic growth is the unrealistically heavy drag of Federal income taxes on private purchasing power, initiative, and incentive."12 Nevertheless, in proposing a rate reduction in order to increase consumption expenditures, he was at pains to point out that this would in turn stimulate investment to help businesses meet the increased demand. Thus, he said, "[O]ur tax system still siphons out of the private economy too large a share of personal and business purchasing power and reduces the incentive for risk, investment, and effort."13 The enactment of the rate reductions in the 1964 Revenue Act has been characterized by Professor Surrey as a watershed in tax policy history, swinging the country over to the "new economics."

Another broad economic policy often suggested as a legitimate concern of the income tax system is the stabilization of the economy. The use of the income tax as a stabilizer of economic activity is not inconsistent with the model described herein and need not detract from equity or neutrality. With a broad tax base, progressive rates, and withholding of tax at the source, the tax is highly responsive to changes in economic activity, and this response will be countercyclical..$^{15}$ Thus, the desire to use the tax for this purpose seldom leads to any demand that the tax system be moved away from the proposed model. Rather, it may be a positive force in pushing for an extensive broadening of the tax base.

Recognizing that the pressures to simplify the law and to provide a variety of economic incentives or barriers will undoubtedly play a role in shaping any new income tax law, it is still possible that a radical revision could be made to achieve greater equity and neutrality in our tax law, and this kind of change would be more likely to occur if it could be done in a way which would minimize the disruptive and dislocative effects of change. The nature of the change itself need not be exactly defined for present purposes, but it might well involve a complete restructuring of the definition of taxable income and perhaps a substantial change in the rate structure as well.

\section{B. Possible Changes in the Concept of Income}

It is relatively easy to find agreement for the statement that taxpayers having equal amounts of income should pay equal amounts of tax. But what is equal

\footnotetext{
${ }^{11}$ Revenue Act of 1964,78 Stat. I9 (codified in scattered sections of INT. Rev. Cone of I954).

${ }^{12}$ Message From the President of the United States Transmitting Recommendations Relative to a Revision of Our Tax Structure, H.R. Doc. No. 43 , 88th Cong., Ist Sess. I (1963).

${ }^{13}$ Id. at 2.

14 Surrey, supra note 8 , at 478 .

${ }^{15}$ Pechasan, supra note 8 , at ro-I6.
} 
income? What, in fact, is income? On this issue there may be substantial consensus on theoretical income but wide differences concerning what can, as a practical matter, be treated as income by the tax system. There is almost universal agreement today on the so-called Haig-Simons definition of income from a theoretical standpoint. A person's income is defined as the sum of his consumption expenditures and his increase in net worth. The tax reform project of the American Bar Association's Section of Taxation has proceeded on this premise. ${ }^{16}$ The Carter Commission, in studying the reform of the Canadian tax system, committed itself to this definition of income, ${ }^{17}$ and it is accepted by economists generally. ${ }^{18}$

To apply this definition rigorously for tax purposes to every element of gain is impractical. ${ }^{19}$ Such a taxing system could not be administered, nor could it obtain widespread taxpayer agreement and understanding. Obviously the model must be adapted to these practicalities, but it need not be thought that it is thereby rendered useless as a standard. Even the most exacting scientific standards accommodate themselves to tolerances of error which are acceptable to the end result. No insurmountable difficulties should be encountered in describing those penumbras of uncertainty about a system of tax which is inherently uncertain. Thus a model system should use a practical approximation of the Haig-Simons definition of income. The result would be a tax base much broader in its reach than we now have in the United States. Major changes in our existing law would be required, and to make all such changes at one time would be disruptive in the extreme to many economic relationships which have been created in reliance on the existing tax base.

\section{Possible Changes in the Rate Structure}

In achieving vertical equity it is necessary to decide whether the tax should be simply proportional to the quantity of income or should employ progressive or regressive rates. This country has generally accepted the idea that the tax system should be a progressive one, achieved not only through the exemption of minimum amounts of income from any tax but also by a graduated rate schedule applied to income in excess of this minimum. However, a system using a flat-rate, proportional tax is gaining some favor among tax reformers. ${ }^{20} \mathrm{~A}$ change to such a rate structure, or even a decrease in the differential between the highest and lowest rates, would also involve some redistribution of the tax burden. This too would be a source of disruption of existing economic relationships unless the transition could be made in a way which would permit a gradual accommodation to the change.

\footnotetext{
${ }^{10}$ Galvin, supra note 6, at 9.

17 I Report of the Royal Commission on TAxation 9-Io (Ig66).

${ }^{18}$ See, e.g., R. Musgrave, The Theory of Public Finance 165 (1959).

${ }^{19}$ See Bittker, "A Comprehensive Tax Base" as a Goal of Income Tax Reform, 80 Harv. L. Rev. $925($ I967).

${ }_{20}$ See GaIvin, supra note 6, at I3-I4; A. Ott \& D. Ott, Summary of Major Findings, in Studies In Substantive TAX REFori, supta note 6 , at 3I, 32-33.
} 


\section{The Political and Economic Barriers to Changing Taxes}

\section{A. The Political Context}

Except in the case of purely technical changes in the tax law, the two primary considerations in evaluating the political and economic implications of any change are the effect of the change on total government revenues and on the distribution of the tax burden. Congress and the President must, of course, measure the over-all impact on revenues, and, as the Tax Reform Bill of 1969 moved from one step of the legislative process to another, the importance of this consideration was spotlighted for all to see. The arguments for and against decreases or increases in total tax collections are largely economic ones. An increase in collections is said to inhibit consumption, thereby slowing the growth of the economy. A decrease in total revenues is said to increase consumption expenditures and contribute to the inflationary spiral. Strong political pressures, arising out of a variety of views about the state of the economy and the nation's budgetary needs, come into play in deciding for or against a change in the law, and these pressures have very little to do with the desire for tax reform. It is simply an exercise in politics and macroeconomics.

The average voter has only a vague understanding of the way the economy is affected by these changes. He tends to regard the change as good or bad depending on whether he believes it will lower or raise his own taxes. Because of his ignorance of the facts affecting his own interests, he may be easily influenced by partisan rhetoric of the politicians, and he is too easily satisfied by such gimmicks as an increase in the personal exemption. ${ }^{21}$ Thus, the small taxpayer, rather than having much influence on the decisions of political leaders, probably is greatly influenced by those political leaders in whom he is most likely to repose his trust.

Of course, the taxpayer's clear bias for taxes that go down rather than up is no doubt a major influence on Congress in shaping a tax measure. Congressmen are loath to raise the tax bills of any substantial number of people and normally strive to give the appearance that everyone is getting a reduction in taxes. Thus, in the

\footnotetext{
${ }^{21}$ Notwithstanding the fact that the tax relief provided by an increase in the exemption is distributed disproportionately to taxpayers in the higher tax brackets, Senator Gore, in arguing for an increase in the exemption to $\$ 1,000$ per person stated, in justification, that "This is the form of relief that will be most easily understood and will provide the most benefit to the average taxpayer." S. REP. No. 552, 9Ist Cong., Ist Sess. 3I4 (Ig69). Taking the statistics presented by Senator Gore and those prepared by the Treasury Department (TAx Reform Studies, supra note $\mathrm{I}$; at 68), the distribution of the tax savings from the Gore proposal would have been as follows:
}

$\begin{array}{ccc}\text { Adjusted Gross Income } & \begin{array}{c}\% \text { of Total } \\ \text { Returns Filed }\end{array} & \% \text { of } \\ 0-\$ 7,000 & 53.7 & \text { Tax Relief } \\ \$ 7,000-\$ 15,000 & 38.8 & 30 \\ \$ 15,000-\$ 50,000 & 7 & 50 \\ \text { over } \$ 50,000 & 0.5 & 17.5\end{array}$


I969 legislative process, most of the changes that were proposed to limit the use of tax preferences were balanced by some offsetting rate reduction that would permit Congress to announce to most of the public that their taxes had been reduced, not increased.

The difficulty lies in the fact that genuine tax reform will call for redistributing the total tax burden in such a way that some taxpayers will be required to pay substantially more while others will have their tax liabilities somewhat reduced. Those whose tax bills will be going up are usually a rather easily identified group with strong group affinities. In 1969 the primary targets were real estate investors, investors in tax-exempt bonds, mineral producers, investors with unrealized capital gains, mutual savings banks, nonfarmer investors in farm operations, and timber growers, among others. The numbers making up any one group are generally small, but these groups frequently wield political power inordinately great compared to their numbers. For this reason, attempts to increase their tax burdens have traditionally been resisted by well-organized and well-financed campaigns to persuade Congress that any increase in their taxes would undermine the economy, the national defense, vital industries, and so forth. The year 1969 was no different, and few voices were heard in specific defense of the proposed changes.

The bulk of the taxpayers may grumble about high taxes, loopholes, and the failure of the rich to pay adequate taxes, but they hardly understand the stakes involved when testimony is presented to Congress against specific proposals. The failure of taxpayers to understand the magnitude of what is involved and how they are affected is largely responsible for damping any effective political pressure which they might exert where their own interests are clearly concerned.

In a year such as 1969 , with great concern being felt because of accelerating inflation and a desire to grant general tax reductions, Congress did get pushed into adopting some provisions that tightened the system and tended to expand the tax base. But most of the changes were severely hamstrung by limitations and exceptions, and it remains to be seen whether or not tax lawyers and accountants will eventually outflank most of them. It is predictable that Congress will continue to find reform an almost impossible objective unless the change is made in such way that the economic and political pressures operating against it will be substantially muted.

\section{B. A Debate Over the Politics of Taxation}

Recently, a debate surfaced between Professor Bittker on the one hand and Professor Musgrave, Dr. Pechman, and Dean Galvin on the other as to whether, in working for reform of the tax laws, it is useful or practical to define a model tax system having as its base some theoretically precise concept of income. ${ }^{22}$ In part,

\footnotetext{
${ }^{22}$ Compare Bittker, stupra note 19, with Musgrave, supra note 6; Pechman, Comprehensive Inconse Taxation: A Comment, 81 Harv. L. Rev. 63 (1967); Galvin, More on Boris Bittker and the Comprehensive Tax Base: The Practicalities of Tax Reform and the ABA's CSTR, 81 Hanv. L. Rev, 1016 (1968). These articles were later reprinted with further comments in B. BitrKER ET AL, A CoMpRE-
} 
the debate concerns itself with the political process of changing the tax laws. Bittker opened this argument with an attack on the proponents of reform who were increasingly speaking in terms of levying a tax on a comprehensive tax base and thus closing loopholes, eliminating preferences, and so forth. He catalogued a large number of issues and types of economic gain which he felt could not be dealt with by reference to some ideal concept of a tax base. He concluded that

[The] reasons for departing from the Haig-Simons definition are, in my opinion, no different from the reasons that are offered in support of all of the "preferences" of existing law: the necessity or desirability of avoiding difficulties in valuation or enforcement, of stimulating economic growth, of encouraging behavior thought to be socially useful, of alleviating economic hardship, of retaining the freedom of choice that results from use of tax concessions rather than some other governmental mechanism, or of pursuing other social policies. ${ }^{23}$

Thus he seemingly took the position that it was necessary, if one were to be realistic about the tax law, to consider each provision of the law, its rationale, its continuing utility and fairness, on an ad hoc basis, a process he believed to be "a discouragingly inconclusive process that can derive no significant assistance from a 'no preference' presumption that would at best be applied only on a wholly selective basis." ${ }^{24}$

In this way, Bittker argued vigorously for the approach to tax legislation which has characterized the approach of our Congress at least since the advent of a steeply graduated rate structure during World War II. Since that time, if not before, the reference point in any legislative discussion of a tax bill has been the existing law; each change has been considered on its own merits, using the ad hoc method defended by Bittker as the only method possible.

Musgrave and Pechman appear to differ with this approach only in principle, and perhaps in where they lodge the burden of persuasion with respect to any projected change in the law. In principle they both appear willing to construct a new law adhering to the Haig-Simons definition of income and then make selective changes in it in order to accommodate the demands of simplicity and prevailing economic and political policies. However, in practice, each recognizes the political impracticability of changing to such a new law in one fell swoop. Musgrave, in particular, accedes to the piecemeal achievement of reform in the law, and he is not uncomfortable about admitting a willingness to accept a departure from his model in the interests of other desirable policy goals. ${ }^{25} \mathrm{~A}$ proposed change would be viewed as meritorious if it moved closer to his reference point, and other policy reasons would have to be considered to override the demands of fairness in the

henstve Income Tax Base? A Debate (1968). See also Bittker, Comprehensive Income Taxation: $A$ Response, 81 HARv. L. Rev. 1032 (Ig68).

${ }^{33}$ Bittker, supra note r9, at $98 \mathrm{r}$.

24 Id. at 982 .

${ }^{25}$ Musgrave, stipra note 22, at 52-53. 
system if the change were not to be made. Bittker, on the other hand, although he does not expressly so state, would appear to accept the status quo as reflecting the current balance of political, economic, and other policy considerations; any proposed change would presumably have to offer persuasive reasons that the old law no longer provides that nice balance.

Galvin, in a debate with Bittker, sponsored by the American Enterprise Institute for Public Policy Research, has suggested a possible middle course, and he has specifically articulated this as a procedural question, a matter of how we are to achieve a transition. He said,

[T] he first part of my case in chief was to carry you to the outermost limits of the Haig-Simons definition for base-broadening purposes. This went very far, very fast, and the immediate and expectable response was some digging in of heels, for, quite naturally, each person begins to think of problems of transition. . . .

... [T] There is no disagreement in principle about the desirability of closing the gap between real income and reportable income. The difficulties relate not to principle but to a function of time, a procedural, not a substantive problem. If we accept base broadening as a principle, and I believe we do, then let's set as a goal the time for its accomplishment. For example, the Congress might set each year an approximate percentage of the gap to be closed between real income and reportable income. ${ }^{26}$

Thus the idea of moving by gradual steps to a broadened base is suggested. The law has indeed been moving in gradual and halting steps in this direction since Ig6r. Perhaps because of the influence of the study conducted by the House Ways and Means Committee in I959 on tax reform, and surely influenced by the effective and patient advocacy of Surrey during his tenure as Assistant Secretary of the Treasury for Tax Policy, the changes made in the income tax have, since Ig6r, slowly been broadening the base. At the same time there has been some movement towards reducing the rate of taxation. Of course, this process proceeds in fits and starts, and for every two steps in that direction there is one step back.

\section{How the Tax Law Breeds the Interests That Oppose Its Change}

Each step toward broadening the tax base in the rg6os was a grudging one because of the very nature of the political process, and one must wonder whether such a process will ever reach the goal of a truly equitable distribution of the burden of taxation. The difficulty lies in large part in the ways in which people adjust their affairs to a tax system. Clearly, the economic system does adjust to a particular tax law. Competition for capital and services strives for the maximum after-tax return, and the consequent competitive lines are drawn on the basis of the various provisions of the Code. Accordingly, after-tax earnings of various types of businesses tend to come into equilibrium, suggesting that, at least in the long

\footnotetext{
${ }^{20}$ Galvin, Rebuttal, in C. Galvin \& B. Bittrer, The Income Tax: How Progressive Should It Be? 74 (rg69).
} 
run, taxes tend to be shifted from business taxpayers to their customers and work force. An excessive rate of after-tax return in one industry will tend to draw capital into that industry until competitive pressures bring its rate of return into line with that of other industries. Any tax change is therefore disruptive. Even if the amended law is more neutral, the change itself is decidedly not neutral in its impact. It will upset an existing balance, adversely effect investments made in reliance on the pre-existing tax situation, and provide windfalls to some. It is entirely understandable that there will be anguished protests made to Congress.

This type of depressant on tax reform legislation was demonstrated time and again in the shaping of the Tax Reform Act of 1969 . One vivid example was in the modest changes which were variously proposed in the treatment of municipal bond interest. No serious proposal was made to subject the interest on such bonds to a full tax, but the bill reported by the House Ways and Means Committee and passed by the House did require that interest on future issues be treated as preferential income for the provision requiring allocation of personal deductions. ${ }^{27}$ Further, it treated all municipal bond interest as preference income for the minimum tax provisions. ${ }^{28}$ It also proposed a subsidy for future issues of municipal bonds should the local government unit elect to issue taxable bonds. ${ }^{29}$ Finally, it taxed in full the interest on arbitrage bonds. ${ }^{30}$

A great many witnesses appeared before both the Ways and Means Committee and the Senate Finance Committee to oppose all of these measures, ${ }^{31}$ and the impact of the legislation on the markets for municipal bonds received great attention from most of the witnesses as well as the committees of Congress. In addition, the inequity to existing holders of municipal bonds came in for some attention in the debate over the merits of the proposed legislation.

Of prime concern was the competition for investors' money between state and local governments on the one hand and corporations and the federal government on the other. All fifty governors endorsed testimony that the legislation would have a disastrous impact on the ability of local governments to finance needed improvements. They pointed out that yields on tax-exempt bonds had climbed precipitously during the period from February I969 (just prior to the release, by the Joint Committee on Internal Revenue, of the Johnson Treasury report recommending a minimum tax) to September I969, following enactment of the above provisions by the House. Governor Tiemann of Nebraska testified that the Dow Jones Bond Buyers Index of twenty representative municipal bonds had risen from 5.04 per cent to 6.02

\footnotetext{
${ }^{37}$ H.R. 13270, 91st Cong., Ist Sess. $\$ 302(a)$ (I969), which would have added $\$ 277$-Limitation on Deductions for Individuals-to the INT. REv. CODE of I954. See especially $\S 277$ (c)(2)(B).

${ }^{28} I d$. $\S 30 \mathrm{I}(\mathrm{a})$, which would have added $\$ 84$-Disallowed Tax Preferences-to the Code. See especially $\$ 84(c)(I)(C)$.

${ }^{20} I d$. $\$ \S 60 \mathrm{I}-02$.

${ }^{80} I d$. $\S 60 \mathrm{r}(\mathrm{b})$, which would have added $\S \mathrm{I03}_{3}(\mathrm{~d})$ to the Code.

${ }^{31}$ I 969 House Hearings, supra note 2, pt. 6, at 2185-354; Hearings on H.R. 13270 Before the Senate Comm. on Finance, 9rst Cong., Ist Sess., pt. 4 (1969) [hereinafter cited as 1969 Senate Hearings].
} 
per cent during that period, while yields on corporate bonds and twenty-year U.S. Government bonds had risen only .44 and .I2 percentage points, respectively, during the same time. ${ }^{32}$ The conclusion they all drew was that the enactment of the House Bill had already had a serious effect on tax-exempt bond prices and that this had caused a more dramatic rise in yields than had occurred in the taxable sector. They argued that were the bill to become law, the narrowing of yields between tax-exempt bonds and taxable securities would continue further and ultimately cost the American people far more in additional interest costs than the additional revenue that would be received at the federal level.

Opposed to this policy argument was the issue of fairness among taxpayers. Congressman John Byrnes of Wisconsin made this point in a colloquy with John Thompson, an investment banker who had testified that the jeopardy to the localgovernment bond markets was too high a price to pay for whatever equity might be achieved by the change:

Mr. ByRnes. My only point is that he [the investor in tax-exempt bonds] wants more than just the difference in the yield between the nontaxable and the taxable bonds.

Mr. Thompson. Oh, yes; he wants more and part of the more he wants is margin to protect him against changes in his tax situation.

Mr. ByRNes. This raises may next point. You suggest that the erosion of tax equity is not serious enough to require you to pay the price of correction.

As I understand the gist of your argument, you are saying that the price you have to pay to create this equity is too high a price. But we have to balance the need for fairness and equity in considering the desirability of paying the price.

At least we would retain the confidence of the people in the fairness and equitableness of our tax laws by paying the price. Where is the point at which tax rates make it to the individual's advantage to buy a tax-exempt municipal bond?

Mr. Trompson. Based on our chart here 30 percent is the break-even point.

Mr. ByRnes. That is the marginal rate.

Mr. Thompson. That is what our charts indicate; yes.

Mr. ByRnes. A person who is in the 45 -percent rate would derive an advantage from buying municipals.

Mr. Thompson. Yes.

Mr. ByRnEs. But he pays the same price, does he not, as the person in the 65-percent income tax bracket? The market sets the rate on any given issue.

Mr. THompson. This is right.

Mr. ByRNEs. There you have, it seems to me, part of the inequity involved when an element of income is completely exempt from any taxes. The inequity just between those at the 30-percent rate, but also between those in the 40-, 45-, and 50-percent brackets. Higher maginal rate increases the advantage even though the yield-exclusive of the tax benefits-is the same. Is that right?

Mr. Thompson. Yes. 33

${ }^{32}$ Statement of Governor Norbert T. Tiemann, 1969 Senate Hearings, supra note 3r, pt. 4, at 3023.

${ }^{33}$ r 969 House Hearings, supra note 2, pt. 6, at 2299. 
The statistic referred to by Byrnes and Thompson had earlier been the basis for a rebuttal by Professor Surrey to the idea that tax-exempt status was necessary for the financing of state and local bond issues. In testimony before the Ways and Means Committee, he argued,

[T]ax exemption only appeals to a certain group of people. Consequently, the market for these bonds is narrow. That is the big problem facing State and local governments. With the great flood of securities that they must issue, the present market for their tax exempts is too narrow unless their interest rates are to rise considerably, which becomes self-defeating. ${ }^{34}$

Thus, Congress had also to consider the possibility that the tax-exempt privilege was in fact inhibiting the sale of tax-exempt bonds by unduly restricting the number of potential buyers. But the state officials would not accept that argument, and they pounded at the theme that any change in the treatment of local government bond issues would be such a breach of faith with American investors who have relied on tax-exempt status that the investing public would never again have confidence in the tax treatment that would be afforded these bonds.

The accuracy of their testimony is, of course, largely dependent upon the underlying reason for the rapid increase in yields of tax-exempt bonds. If the sharp narrowing of the spread between tax-exempt yields and corporate yields which occurred following the hearings held by the Ways and Means Committee (from thirty per cent to twenty per cent) can be traced to the possibility of passage of the Treasury proposals, and not to the drying up of investment money, it had to be the result of psychological factors more than economic ones. Congress was told that over fortyfour per cent of these bonds were held by banking institutions and only thirty-two per cent by individuals; yet neither the Treasury proposal nor the House Bill would have affected corporate taxpayers. Witnesses, however, were fearful of a continuation of the psychological reaction and many defended it as national investment policy. They argued that if the government breached faith with some investors even in this limited way, investors would conclude that such steps were only a beginning and that eventually the tax privilege afforded such bonds would be destroyed completely. ${ }^{35}$

In the end, Congress resolved this dispute against tax reform, accepting the argument that to make any change would disrupt the market for municipal securities. Only one provision was retained and that was the elimination of the tax-exempt privilege for arbitrage bonds. To end that clear abuse of the privilege was hardly likely to offend investors. The Senate even struck the provision of the House Bill

\footnotetext{
${ }^{34}$ Id., pt. 4, at 1633 .

${ }^{35}$ Statement of Frank C. Carr, 1969 House Hearings, pt. 6, at 228r; Statement of W.W. Dumas, 1969 Senate Hearings, supra note 3I, pt. 4, at 2997-98; Statement of Norbert T. Tiemann, supra note 32, at 3024; Healy, The Assault on Tax-Exempt Bonds, reprinted in Statement of C. Beverly Briley, 1969 Senate Hearings, stipra note 28 , pt. 4 , at 3067 .
} 
that would have permitted, but not required, state and local governments to issue taxable securities. ${ }^{36}$

On many other subjects, Congress was deluged with testimony from interested parties. In the view of these partisans, to make even small changes in existing tax privileges would seriously damage the country by upsetting established economic relationships. Thus, to change the depletion allowances would be to break faith with thousands of investors who had built an entire industry in reliance on existing depletion arrangements; to change the provisions by which farm losses are permitted to shelter other investment income would damage the nation's capacity to produce enough food; to change the real estate depreciation rules would seriously impede a needed flow of capital into residential construction; to change the extremely favorable rules with respect to gifts of appreciated property to charities would make it impossible for private charities, welfare agencies, schools, and colleges to continue to obtain adequate financing. Every change was seen as dramatic and as unfair not only to those who had previously relied on provisions of the law but to those who had not yet had an opportunity to take as full advantage of them as they might like.

It is to the credit of Congress that in the face of this enormous pressure, it manages to make at least some changes from time to time. It is not that the pressure is evil or extortionist in nature but that it is difficult to resist because the arguments put forth have merit. The policies for which witnesses stump are ones with which most people would agree. Also, the money at stake is enough that advocacy for the policies and their implementation through the tax law is of high

\footnotetext{
${ }^{36}$ The impact of these securities on the federal revenue, as compared with the corresponding benefits inuring to the states from lower interest costs, was a matter of concern to the House Ways and Means Committee, which noted, "Historically, the ratio of yields on tax-exempt issues to taxable issucs has been as low as 60 percent, but in recent years it has been close to 75 percent." H.R. REP. No. 91-4I3, 9Ist Cong., Ist Sess., pt. 1 , at 172 (I969). The narrowing of this gap has reduced the marginal bracket in which tax-exempt bonds yield an equal return with taxable issues from $40 \%$ to $25 \%$, thus increasing the number of taxpayers able to shelter income as well as increasing the amount of shclter at each marginal level. "Recent estimates place the annual saving in interest charges to State and local governments at $\$ \mathrm{I} .3$ billion, but the annual revenue loss to the Federal Government has been estimated at $\$ 1.8$ billion." Id. at I73.

However, the testimony on this issue was not unmixed. A survey based on 1964 data was introduced to show

"that only ro percent of the persons with incomes of over \$ro,000 owned any municipals and that only I percent of them derived as much as 25 percent of their income from such securities. While 65 percent of these persons in the highest category, those with incomes of $\$ 315,000$ or more, held some municipals only $x 8$ percent of them derived as much as 10 percent of their income from this source, and only 6 percent derived as much as 25 percent from this source." Statement of Frank C. Carr, supra note 35, at 2282.

Since the total impact and its distribution among taxpayers was as unclear as the issue itsclf was controversial, the Senate deferred any changes in the tax status of these bonds. In an obvious attempt to enhance the supply of relevant information available for future consideration of the issue, the Finance Committee added a reporting provision to its version of H.R. 13270 whereby "every person who receives or accrues $\$ 600$ or more of interest on tax-exempt State and local government bonds (or who is required to file an income tax return for the year) is to make a return setting forth these amounts." S. REP. No. 9I-552, 9Ist Cong., Ist Sess. 218 ( 1969 ). This, too, was cut from the final bill.
} 
caliber. Thus it is not only the quantity of the pressure, but also its quality, which impedes tax reform. To press forward with reform in the face of this pressure requires that Congress have the ability to step back from all the individual arguments and see them as part of a broader view of the entire tax system and the way in which the system distributes the tax burden among taxpayers.

It is likely that the tax-writing committees of Congress do see these issues in perspective; but they have not as yet been overly successful in finding a way to reform the law without creating drastic losses for some and huge windfalls for others as economic and competitive factors adjust to the change in the law. So if a way were found whereby the law could change slowly toward a model system, but with both an inevitability and a defined certainty, investors, consumers, governments, and, of course, taxpayers would have a substantial period of time in which to make their economic adjustments, reasonably secure in what changes would be made and when. This could well be what is needed to mute the opposition to real reform.

\section{III}

\section{Three Methods of Expanding the Tax Base, Evaluated}

\section{as Transitional Mechanisms}

In its consideration of the Tax Reform Act of 1969 , Congress considered two proposals which were not enacted but which appear to hold out some promise as a means of eventually facilitating orderly and gradual change to a tax system having a much broader base. These were (I) the proposal of the Treasury Department during the Johnson administration for a minimum tax and (2) the proposal of the Nixon Treasury for a limit on tax preferences (LTP). Unfortunately, both approaches were scrapped by the Senate in favor of the "minimum tax for tax preferences" now contained in sections $5^{6}$ to $5^{8}$ of the Internal Revenue Code. The change was made in the interest of simplicity, but in this instance it may well be that the balancing of interests was not done with enough foresight and that a choice of the "more complicated" method of either the minimum tax or the LTP would, in the long run, have resulted in greater simplicity as well as greater fairness in the tax law. An examination of these three methods of mollifying those who were complaining about 155 taxpayers with incomes in excess of \$200,000 who had paid no income tax in 1967 may be of value should Congress decide in the future that the "minimum tax for tax preferences" leaves something to be desired.

\section{A. A Minimum Tax-The Johnson Treasury Proposal}

The minimum tax which the Treasury proposed in rg68, and on which the House Ways and Means Committee heard testimony in its hearings in March and April 1969 , was a true minimum tax. ${ }^{37}$ It involved an alternative computation

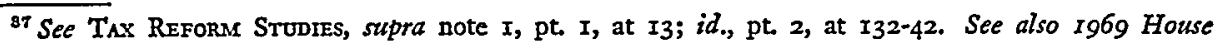
Hearings, supra note 2, pt. 5, at 1773-809; id., pt. 7, 2355-63. .
} 
of tax based on a recomputed base of taxable income and an alternative rate schedule, the taxpayer being obligated to pay the higher of the amounts arrived at in the two computations. The new rate schedule proposed by the Treasury would have been roughly one-half the rate schedules then in effect, but it is readily apparent that the rate schedule could have been set at any level, perhaps being some particular percentage of the existing schedule or being flattened out or steepened in its progressivity.

The expanded tax base was to be determined by adding to taxable income (computed in the normal fashion) four items which the Treasury considered to be major sources of excluded income: (I) interest on state and local bonds, (2) the excluded portion of net long-term capital gains, ${ }^{38}$ (3) the amount of percentage depletion claimed after the cost of the property had been recovered, and (4) the untaxed appreciation in value of property contributed to charity. The items to be added to taxable income to obtain the expanded tax base need not have been that particular four, nor need they have been limited to that number. For example, an obvious candidate for inclusion would have been untaxed appreciation in value of property transferred by reason of death. And an even greater expansion of the tax base would result from disallowance of all nonbusiness deductions and exemptions. ${ }^{30}$

The Treasury proposal also contained a provision that would have required a proportional allocation of certain deductions to the excluded income. The deductions to be allocated were certain personal, as distinguished from business, deductions consisting of interest and tax payments, casualty losses, charitable contributions, medical expenses, and cooperative housing expenses. The portion of the deductions allocated to the items of excluded income would have been disallowed as deductions in computing the regular tax.

These two provisions-the minimum tax and the allocation of deductions-were commonly linked in commentary about the Treasury proposal. Both had as their purpose an attack on the use of a combination of deductions and excluded income items to reduce greatly or even to eliminate altogether the tax liability of individuals having relatively large amounts of economic income. However, although the two provisions were treated as a package, they were, in fact, independent of one another. No allocation of deductions was required for determining the minimum tax, making its computation extremely simple. It required only that taxable income be increased by the four items of excluded income. To this a separate rate schedule would be

\footnotetext{
ss While this exclusion amounts to $50 \%$ of net long-term capital gain income for taxpayers whose marginal bracket is $50 \%$ or less, the operation of the $\$ 1201$ alternative tax computation raiscs the cxclusion above $50 \%$ for taxpayers in higher marginal brackets. Since the maximum statutory rate for capital gains taxation was $25 \%$, a $70 \%$ bracket taxpayer effectively excluded $64 \%$ ( $100 \%-\frac{25 \%}{70 \%}$ ) of such gains from income. The Treasury proposal would have included the entire $64 \%$ in the minimum-tax basc. TAX REFORM STUdies, supra note 1 , at 133 .

${ }^{89}$ See Galvin, supra note 6 , at $9-\mathrm{I} x$.
} 
applied, and the two tax figures would be compared. The taxpayer would be obligated to pay the higher of the two amounts.

The minimum tax proposal was criticized as setting up a second tax system parallel to the existing system. Assistant Secretary of the Treasury Cohen testified, "The minimum income tax ... would require a separate tax calculation which would itself be a source of complexity. We believe that our proposal, which works within the structure of the existing income tax rates ... is an improved method of dealing with the problem of putting an overall limit on tax preferences." fact, the additional calculation would not have been difficult in practice, being substantially simpler than the present alternative tax calculation for capital gains, and should not have created any administrative difficulties. Cohen's criticism on grounds of complexity therefore does not seem valid, especially if the minimum tax is compared with the limit on tax preferences proposed by the Treasury Department in April I969. The calculation of the limit on tax preferences was a more cumbersome one in principle than the minimum tax of the Johnson Treasury, and it was made even more complex by a five-year carryover of disallowed preferences and by adjustments to take into account net operating losses.

The minimum tax, because it was a parallel tax system with a separate tax computation, was an ideal instrument for changing from the present tax system, which employs a narrow tax base, to a system employing a greatly expanded tax base. By initially employing a relatively low rate structure for the minimum tax calculation on the expanded tax base, the alternative tax would have affected very few individual taxpayers at first. In succeeding years the number of taxpayers required to use the alternative calculations could have been gradually increased by increasing the rates by some fixed percentage each year. For example, if it was thought that a rate structure ranging from ten to forty per cent would provide an ideal degree of progression for a model tax system, the rate structure for the minimum tax might be set initially to range from two to eight per cent. Over a period of years it could be slowly increased to the desired schedule of ten to forty per cent. Obviously, as the rate schedule for the alternative calculation increased, the number of taxpayers using the alternative computation would increase, as would the revenue derived from this method of computation. To compensate for this increase in revenue from the parallel system, the rate structure on the regular tax base could be gradually reduced. In this manner, the parallel system would eventually reach all of the taxpayers who would be substantially affected by a change to the expanded tax base. The original system could then be abandoned, and all taxpayers would be required to report on the system that had begun as an alternative minimum tax.

As a result of phasing in the new system over a period of ten to fifteen years, relatively few taxpayers would become subject to the minimum tax in any given year, and the increase in tax for all taxpayers affected by the minimum tax would

\footnotetext{
${ }^{10}$ Statement of Edwin S. Cohen, I697 House Hearings, supra note 2, pt. 14, at 54-85.
} 
also be relatively small in any given year. There would be no sudden and drastic change in economic or competitive relationships affecting one group of taxpayers vis-à-vis others, and there would be substantial opportunity for adjusting affairs to minimize the impact of the change. Because transition would be less painful, the strength of resistance to the tax changes being thus implemented would be lessened.

Although the Treasury proposal called for a minimum tax only on individuals, there is no reason why the same transitional method could not be employed for corporations. A set of normal and surtax rates would be chosen at a relatively low level, say five and one-half per cent and twelve per cent, and this could in slow stages be moved toward the levels chosen as ultimately desirable. Again, as revenues increased as a result of the parallel system, it would be feasible to make a reduction in the existing normal and surtax rates for corporations generally. Eventually, as in the case of the individual system, the parallel system would completely replace the existing one, and all corporations would employ the expanded tax base with a somewhat reduced rate schedule.

\section{B. A Limit on Tax Preferences-The Nixon Treasury Proposal}

Following the change of administrations in January 1969, the Treasury Department revised its proposals. The new proposals were submitted by the Nixon administration to Congress in testimony before the House Ways and Means Committee in April rg69. It proposed a "limit on tax preferences" as a substitute for the minimum tax. This proposal called for scrapping the parallel tax system of the earlier Treasury report and substituting an expansion of the tax base for taxpayers who had relatively large amounts of tax preference income. The computation would have required that the taxpayer add to his adjusted gross income (exclusive of long-term capital gains) all of his tax preferences; fifty per cent of this sum (but not less than $\$ 10,000$ ) would then have been the limit of the tax preferences allowed him. If his total preference items exceeded the limit, the excess would have been added to taxable income and subjected to tax at ordinary income rates.

Structurally, it can be seen that the limit on preferences could be set at any level from zero to roo per cent and could be reduced over a period of years as a transitional device. Furthermore, the amount to which the percentage would be applied in determining the limit would not have to remain as adjusted gross income plus tax preferences. It could be gross income, taxable income before disallowance of preferences, or any number of other computed amounts. Thus, although the technique of limiting tax preferences is somewhat more complicated than the Johnson Treasury's proposed minimum tax, it too is capable of being introduced gradually over a period of years. This could be done by reducing the limit on tax preferences by a small amount each year until it reached zero. In such a way, more taxpayers would be subjected to it each year. Total revenues would be increased by these changes, 
making it possible gradually to reduce the over-all rate of tax. A gradual transition to a tax system having an expanded tax base would be the result.

The Nixon Treasury proposal made substantial changes in the items which would be considered tax preferences from the four items of excluded income which the Johnson Treasury proposed to add in obtaining the expanded tax base. The Nixon Treasury's list was as follows: (I) certain appreciation in value of property donated to charity; (2) the excess of percentage depletion and intangible drilling expenses over the allowable amounts of cost depletion and straight-line depreciation that would have been claimed had the expenses been capitalized; (3) the excess of accelerated depreciation on section $125^{\circ}$ property over the amount allowable under the straight-line methods; and (4) certain farm losses if the taxpayer did not adopt a method of accounting requiring an inventory and capitalization of those direct and indirect costs which would be capitalized under accounting methods generally applicable to other industries.

The Nixon Treasury also proposed an allocation of deductions but suggested that different items be treated as items of tax preference to which deductions should be allocated. For this purpose the tax preferences were to include tax-exempt interest and the one-half of net long-term capital gains deductible under section I202.

The House Ways and Means Committee adopted a modified form of the Nixon Treasury proposals, including in their bill a limit on tax preferences and provision for allocation of deductions. The modifications were primarily in the list of items considered tax preferences under the new provisions. For example, tax-exempt interest was to be treated as a tax preference item for LTP but not for the deduction allocation. By the time the bill had reached this stage the operation of the two provisions was indeed somewhat complicated, and this was at least one reason why the Senate Finance Committee, and ultimately the Senate, adopted the minimum tax for tax preferences as a replacement for these two provisions in the House Bill.

\section{The Minimum Tax for Tax Preferences-The Tax Reform Act of 1969}

The Tax Reform Act of 1969 adds a new part VI (sections 56-58) to the Internal Revenue Code entitled "Minimum Tax for Tax Preferences." The Senate Finance Committee stated, in its report that it believed "that this minimum tax will be a more effective and considerably simpler method of imposing tax on preference items than the House provisions." 41 The report goes on to state that the provisions of the House Bill

would greatly complicate the preparation of tax returns for those to whom they apply. Much of this complexity arises from the inclusion of regular taxable income and tax preferences in the same tax base. This presents difficulties wherever there is a limitation on a particular deduction based on income under the regular tax

\footnotetext{
1 S. REP. No. 9I-552, gIst Cong., Ist Sess. II2 (I969).
} 
computation since the limit on tax preferences affects the amount of taxable income and the amount of taxable income in turn affects the particular deduction and the limit on tax preferences. ${ }^{42}$

Thus the Senate Finance Committee, and ultimately the Congress, came full circle to a separate computation of tax on items of tax preference in order to reduce the complexity of the bill. Its solution requires, as did the solution proposed by the Johnson Treasury, a separate computation of tax, but it differs markedly in its utility as a model for accomplishing a transition from our existing tax system to a more broadly based one.

The Senate-developed provision defines "items of tax preference" in new section 57 of the Code. These items are added together, and the excess over the sum of the regular taxes imposed on the taxpayer plus $\$ 30,000$ is subjected to a special ten per cent tax. Special rules are adopted for years involving net operating losses and a variety of other special situations. ${ }^{43}$ All in all, the new part VI of the Internal Revenue Code is a complicated addition.

As previously mentioned, the added complexity from the enacted version of a minimum tax has not been offset by its utility as a mode of transition to a more equitable tax system. Of course, the list of items of tax preference could be used in a subsequent expansion of the tax base, but the tax itself does not provide the means for a gradual replacement of one tax base with another. A convenient transitional mechanism requires either an alternative tax computation incorporating all income items, as in the minimum tax proposal of the Johnson Treasury, or a phasing in of a disallowance of tax preferences for purposes of the regular tax computation, using a computation similar to that involved in applying the limit on tax preferences of the Nixon Treasury.

Furthermore, the special tax on tax preferences cannot operate equitably even within the limits of our existing progressive rate structure. Thus, one taxpayer having items of tax preference on which there is imposed a ten per cent tax might be in a tax bracket having a marginal rate of thirty-five per cent, while another taxpayer's marginal rate might be in the top bracket of seventy per cent. Nevertheless, the rate imposed on the tax preference items of the two taxpayers is identical. ${ }^{44}$

Taxpayers in general can be expected to look askance at the ten per cent minimum tax for tax preferences. Comparing the ten per cent rate with the rate they

\footnotetext{
42 Id. at Ir3.

${ }^{43}$ See Hobbet, Minimum Tax on Preference Items: An Analysis of a Complex Netv Concept, $32 \mathrm{~J}$. TAXATION I94 (1970).

"When the bill reached the Senate floor, Senator Kennedy tried to amend the minimum tax to impose a graduated rate schedule, ranging from $2.5 \%$ to $15 \%$, which would have resulted in subjecting preference items to the same type of progressive tax as already applied to nonpreference incomc. II5 CoNG. Rec. 15,972-76 (daily ed. Dec. 6, 1969). It is conjectural as to whether this would have improved the equity of the tax, because the effective rate of tax on economic income, being a combination of the regular tax on taxable income and the new tax, is the true test of equity, and it would still be only arbitrarily affected by the new tax on preferences.
} 
themselves are paying, they will create pressure on Congress to increase the rate imposed by section $5^{6}$ on tax preferences, but such an increase in the rate of tax would do nothing to alleviate the inequity caused by imposing a flat rate of taxation for tax preference items on every taxpayer regardless of his marginal rate on taxable income. Furthermore, no changes that Congress makes in this direction will have any impact on the expansion of the tax base. Thus, it is simply a revenue-raising device, and the only hope it holds for an eventual transition to a better tax system is that the additional burden of tax on taxpayers having items of tax preference will increase to a point at which they will not object to enactment of an expansion of the tax base and a general reduction of tax rates, as a package, as a replacement for the minimum tax for tax preferences.

\section{Basis Problems}

One of the difficult questions that the Senate encountered in drafting the minimum tax for tax preferences was whether any attempt should be made to adjust the basis of property which had generated tax preference items. For example, in the case of restricted or qualified stock options, the statute prescribes that the excess of the fair market value of the stock over the exercise price shall be considered an item of tax preference at the time the option is exercised. The Senate had to decide whether or not some adjustment to the basis of the acquired stock would be in order because of the tax that would be paid on this item. The Senate elected not to permit a basis adjustment, in large part because of the complications that would be introduced into the statute in attempting an equitable adjustment. The result is that the same gain which is taxed at a ten per cent rate under the minimum tax for tax preferences will be taxed again upon the sale of these securities. Because of the postponement of the tax liability this may not be unduly inequitable as long as the minimum tax rate is held at ten per cent. If, however, the minimum tax rate is increased in the future, the inequity resulting from failure to permit a basis adjustment would increase.

Less difficulty exists with respect to a minimum tax proposal similar to that of the Johnson Treasury. As the rate schedule for the parallel tax system increases to a level where the double tax resulting from a failure to make a basis adjustment seems inequitable, it would be simple enough to provide that for any taxpayer required to pay a tax computed according to the parallel system, the basis of his property would be adjusted by the amount of any depreciation and depletion allowances, any receipts of certain income items (such as in the stock option situation), and other like items which are taken into account in computing the minimum tax. It would make no difference whether the taxpayer is subjected to the minimum tax one year and the ordinary tax in the next year. The basis would be rather easily computed by making the adjustments which would be appropriate under the particular tax base that entered into the calculation of his income tax. 
Basis adjustments under a system imposing a limitation on tax preferences would be possible, but they would be somewhat more complicated than those involved in the minimum tax calculation. If, for example, a taxpayer were allowed the benefit of thirty per cent of his items of tax preference and if these items included $\$ 10,000$ of percentage depletion in excess of cost depletion, it would be possible to provide that only thirty percent of the percentage depletion excess should be taken into account as an adjustment to the basis of the property. It would also be possible to do this in a different way by making basis calculations dependent upon a computation of the tax base without the allowance of tax preference items whenever the disallowed preference items were in excess of some fixed percentage of the total items of tax preference.

In any event it should be quite possible under either the minimum tax or the limit on tax preferences to make equitable basis adjustments without unduly complicating the computations of tax liability or adjusted basis. The same cannot be said for the minimum tax for tax preferences.

\section{ConcLusion}

If due regard is given to transition mechanisms, it is barely possible that the United States could adopt a radically new tax system that would employ a greatly expanded tax base with a rate structure reflecting the electorate's current sense of what is a fair degree of progressivity. Attempts to achieve this type of tax reform have never made much progress in the past, nor is it likely that any such new departure could be enacted in the future without some provision for gradual transition from the present tax system to the new one.

Of course, it has not been uncommon in the past for changes in specific provisions of the tax law to be phased in over a period of several years. In addition, transitional problems arising from changes in the law are now frequently dealt with by making a specific change applicable only to future transactions, future years, or some combination of both, an approach that has contributed great complexity to the administration of the present Code. All of these are transitional mechanisms of a sort, but they are limited in scope because they are peculiarly applicable, not to the Code as a whole, but to specific parts of it. What we are concerned with here is the possibility of a complete overhaul of the existing law, and the transitional mechanism called for is something which we have as yet had no occasion to design and employ.

Nevertheless, the minimum tax proposal of the Johnson Treasury and the limit on tax preferences proposal of the Nixon Treasury each provides a model that might be adapted as a transitional mechanism that would permit a gradual and predictable changeover from the old system to a radically new one. The advantages are both economic and political. Avoidance of serious economic dislocations is of course an important goal. Assuming a transition period of ten years or more, taxpayers 
would have adequate time to adjust their personal affairs to the anticipated change, and the number changing over from one system to the other, or being deprived of particular pre-existing advantages, in any one year would be small enough to minimize the economic impact. Furthermore, the simple fact of deferring the complete changeover for a long period of time would reduce the immediate cost to those who would eventually carry a larger part of the tax burden.

The political benefits of this lessened economic impact would be substantial, for taxpayers would resist less strenuously any measure that avoided serious dislocation of their personal affairs and sudden alteration of conditions in the markets that affect them. Perhaps more important, Congress would concern itself less with imminent individual hardships and windfalls and more with the merits of tax reform itself. Gradualness in phasing in the new tax and perpetuation of some of the faults of the old system may be a small political price to pay for achieving the expanded tax base many are seeking.

The minimum tax proposal of the Johnson Treasury would appear to have the greatest merit as a model for a transitional device. An alternative tax computation, of course, involves some extra labor, but, aside from reporting some additional items, there would be few added problems. Computation of each tax would be relatively simple, because there would be no interaction between the two. Furthermore, many taxpayers would need to make only one computation of tax because it would be readily apparent which one would control liability. The simplification resulting from the eventual changeover to a more broadly based tax would more than compensate for the complexity associated with transition.

The limit on tax preferences approach would be somewhat more cumbersome, and it would apply to every taxpayer who had items of tax preferences. This would involve large numbers of taxpayers if the law were truly reformed, because most if not all of the personal deductions would be treated as items of tax preference. Instead of affecting a new group of taxpayers each year, this approach would gradually expand the tax base of a relatively large number of taxpayers every year. Thus, many taxpayers would be making a different calculation each year over the period of years selected for the transition. Nevertheless, this is a device by which an orderly transition could be made without drastic economic consequences to any taxpayers solely as a result of the change. It is thus to be distinguished from the sudden elimination of certain preferences, which would necessarily have a large and often unfair impact on those taxpayers who had made investments or otherwise relied on the tax preferences being terminated.

In contrast, the present minimum tax for tax preferences holds no promise as a means of changing from existing law to a greatly improved tax system. Since it is just an additional tax and has no effect on the tax base itself, it cannot function as the type of transitional mechanism which is needed. However, it may be of some consequence in achieving reform of the tax law by serving as a constant 
reminder to voters that there are some taxpayers who are more favored than most and who pay only a special ten per cent minimum tax on preference items as a token for the government's inability to collect any other income tax from them. It may be that this fact will gall enough voters so that tax reform will become an issue on which some candidates can successfuly campaign for public office.

Although Congress rejected both of the proposals which could serve well as models for future transitional mechanisms in favor of this latter additional tax, the two rejected methods merit considerably more attention in the future by tax theorists, legislators, and administrators who recognize the need for the United States to eventually achieve a tax system which is more equitable in its distribution of the tax burden. 